\title{
Constructing historical thinking and inclusive identities: Analysis of heritage education activities
}

\author{
Helena Pinto* - University of Porto, Portugal \\ Alex Ibañez-Etxeberria - University of the Basque Country (UPV-EHU), Spain
}

\begin{abstract}
This paper addresses the value of effective, significant heritage education pedagogic activities and tasks when teaching heritage topics in history and social science lessons. Heritage pedagogy needs to challenge students' preconceptions about their heritage and encourage learning about it: the investigation, interpretation and provenance of its sources and its significance. Our article is based on a research project in Portugal and Spain to evaluate the impact of heritage education pedagogy on students' historical understanding and their development of national identity. This paper's research involved secondary school students in northern Portugal. To assess their understanding of heritage, they completed a questionnaire at a heritage site with a focus on buildings, archaeological remains and museum artefacts that related to aspects of national history studied in schools. Analysis of their questionnaires revealed the relationship between students' interpretation of the heritage site's historical evidence and their historical consciousness. Although most students treated the heritage site buildings, remains and artefacts as sources of factual information about a fixed, given and largely unremembered past, several students questioned, hypothesized, and treated the sources as historically contextualized evidence that dovetailed with their existing historical knowledge. Contextualized interpretation is essential to historical understanding; accordingly, students studying heritage should be trained to analyse its historical sources in relation to their historicity. More generally, teaching about heritage should give students opportunities to challenge preconceptions they hold about it, and to learn how to deal with different, contrasting, difficult and controversial interpretations of heritage topics and sites in their historical contexts.
\end{abstract}

Keywords: identity; heritage; heritage education; students' inferences; historical thinking; Portugal; Spain; artefacts

\section{Introduction}

This paper reports research in Portugal on heritage education. Our aim is to analyse the importance of providing heritage education with pedagogic activities and tasks that challenge students' preconceptions about their local heritage history in its national historical context. We argue that enhancing students' interpretation of historical sources about local heritage history involves the development of their ability to think historically. Such cognition involves both historical contextualization and a depth of related historical knowledge and understanding (Pinto, 2016).

A complementary Spanish research project to evaluate heritage education programmes (Fontal and Ibañez-Etxeberria, 2017) has considered the Portuguese 
heritage project's research findings and significance. The Spanish project investigated community, museum and school educators' narratives about heritage, since they influence students' historical understanding of national history and construction of their identities (Chapman and Facey, 2004).

Students have ideas, preconceptions, emotions and feelings about the past that they construct from historical information they encounter and assimilate through their families, local and national communities, the media, and from what they learn at school. Research into students' views about the past within their social contexts can help understanding of how they make sense of the nature and purpose of history (Barton and Levstik, 2004). In turn, this means we can develop effective and meaningful curricula, syllabuses, programmes of study and pedagogy for history and social studies involving heritage education. Curriculum development requires challenging students' largely sensory and affective experience of heritage education sites, and questioning both their historically based assumptions and the evidence on which they are based. Since local communities have come to recognize the importance of their historical and cultural heritage background, new heritage categories have emerged, as reflected in an increasing demand for specialists in the field of archaeological heritage. Many archaeological sites have been conserved in situ to provide connections between past and present, as well as substantive remains of commemoration. This creation of a form of symbolic cultural capital contributes to the identity of the locality with regional and national overtones. Everything that surrounds us has a past that is recognizable because we all share that past. Lowenthal (1999: 410) remarks that with the relics we preserve, as with the memories we cherish, we live simultaneously in both the present and past:

Humanity's continuous impact on the relics of the past may seem selfevident, but awareness of it is only recent. Historic preservation has helped us to see how much the past is altered to suit the present. Old buildings and artefacts have long been adapted to new uses, but the impulse to preserve has made such adaptation much more self-conscious.

Heritage, when used to reinforce collective identities, social values and moral orientations, traditionally passes unchanged from generation to generation, involving myth-like narratives, traditions and ceremonies. However, in modern multicultural societies, where previously separate and different, even alien, cultures interact, established educational policies and practices are no longer adequate to bring together and reconcile conflicting traditional views of heritage. They should now be considered on the basis of evidence and argument, since there are various multiple, often conflicting, interpretations of the past. Therefore, to ensure against the transmission of a dogmatic, unquestioned single version of the past, students need to understand the nature and processes of historically based knowledge-making, that is, questioning, investigation, discovery evaluation and uses of evidence in constructing historical analyses, narratives, accounts, arguments and interpretations.

While many national history curricula focus on history as a multifactorial narrative to strengthen national identity and pride, while ignoring wider international dimensions and perspectives (Pinto, 2011), history education research argues that students better understand history when they perceive the linkage between local, national and international events, and more widely discover, and are aware of, the differences and similarities among local and broader communities of belonging. 


\section{Evaluating the use of heritage in education activities and programmes}

Heritage-related education development should not be disconnected from the work of UNESCO, whose conventions (UNESCO, 1972) gradually assigned a more relevant role to education in the management of cultural heritage. Along with concern about the deliberate destruction of cultural heritage, UNESCO acted 'to ensure respect for cultural heritage in society, particularly through educational, awareness-raising and information programmes' (UNESCO, 2003: 67).

Council of Europe (COE) recommendations have also promoted understanding of heritage education as an axiom of heritage sustainability. For instance, in its first heritage education recommendation (COE, 1998), the COE's innovative perspective refers to heritage-based teaching having an active, challenging pedagogy, a wide range of communication modes, interdisciplinary approaches and possible integration of several educational areas (Fontal and Ibañez-Etxeberria, 2017: 178).

Although having a longer tradition in Latin American countries, since the beginning of the twenty-first century developments in European heritage teaching and museum studies involved a fundamental revision of heritage educational practices so as to recognize it as a separate area, especially in Spain (Fontal Merillas, 2003). Four lines of research and development - heritage communication, heritage teaching, heritage education, and curricular matters related to teacher training programmes make possible international comparisons of research findings on heritage education (Fontal and Ibañez-Etxeberria, 2017).

The introduction of heritage education as a separate, discrete subject led to several educational models that share a holistic, identity-driven approach (Cuenca, 2002), a conceptual shift that reflects the evolution of the concept of heritage (Fontal and Ibañez-Etxeberria, 2017: 180), and the bonds and relationships between heritage and the community. Fontal Merillas's (2003) research defined five possible models of heritage education and pedagogy:

(1) The instrumental or utilitarian model includes proposals related to heritage, or its management, with non-educational aims visible mostly in tourist settings. Education makes the management of heritage as a resource more effective in the short term as a stand-alone activity tailored to specific situations and circumstances with scope for informal, extramural education. The instrumental or utilitarian model sees learners, however defined, as heritage consumers.

(2) The historicist model, although concerned with educational goals and specific methodologies, focuses exclusively on the sphere of historical heritage, especially with regard to its conceptual dimension. It refers to educational practices that value the historical dimension of cultural heritage, with its focus on the transmission of, and sensitization to, substantive knowledge of cultural heritage. The main orientation is education as diffusion of essential knowledge and concepts, using a range of strategies that can include digital resources and new technologies, thus enabling individuals to construct independently their own understanding and interpretation of heritage within the locality.

(3) The mediationist model, with clear educational goals, recognizes that the mediation of knowledge and understanding of heritage and its significance is essential for the public and can be detached from heritage management goals per se. Education refers to teaching and learning to make heritage meaningful and significant. Specific constructivist mediation intervention programmes meet a range of medium-term public demands. The mediationist model also 
incorporates evaluation of both the teaching of heritage and its learning outcomes. Mediationism can lead to community-based approaches (usual in Latin America) and is connected to the following model.

(4) The symbolic-social or identity-based model sees heritage as a key player in the symbolic, iconic processes that underpin the construction of identity (Fontal Merillas, 2003: 158). Besides recognizing the symbolic importance of material and immaterial heritage for group identification, from this perspective heritage is taught as a fount of values and, therefore, fosters symbolically their possible assimilation and even appropriation. The social sciences are central to this model. Methodological strategies, analytical instruments and interpretations of data are integral, since they allow awareness of the educational process and promote effectiveness. A problem that may arise is the political, politicized, use of heritage, given its close connection with identity, national or otherwise.

(5) The bond-based model is based on the idea of connections between the resources of heritage and people. It relates to the integration of a range of personal learning experiences of heritage, including public visits to heritage sites, events and activities, the media and specific educational provision.

Currently, there are several emerging lines of research for the evaluation of the impacts of the media and social networks on heritage education. Shaping the direction of research on heritage education are:

- the emerging UNESCO and European Union educational models and innovative didactic designs, along with related guidelines

- the integration of information and communication technologies in teaching and learning as a tool (for example, virtual learning environments, augmented reality, geolocation)

- evaluation models for measuring the impact and effectiveness of heritage education programmes, processes and learning outcomes that national research plans may support (Fontal and Ibañez-Etxeberria, 2017).

These points relate to the research project on heritage's educational use supported by the Ministry of Science and Innovation of Spain (EDU2015-65716-C2-2-R): Evaluation of Programmes and Learning within Formal and Informal Heritage Education. Evaluation was to discover how effectively the programmes met the challenges of social changes and innovations that involve the protection and preservation of culture and heritage. The project based its selected programmes on international standards, with an analysis for each of these of their theoretical focus, goals, the quality of design and planning, implementation and impact, usefulness and value of outcomes. The selected programmes based their design and implementation on awareness, valorization and socialization of heritage, with a focus on the linking of identity and cultural heritage reflecting international criteria.

Evaluation enables understanding of the nature, process, scope and even value of the learning that heritage education programmes generate. Heritage education includes different complementary types of learning - cognitive, attitudinal, ethical, emotional and social. Overall, findings contribute to the redefinition and refinement of criteria for the analysis and design of heritage education programmes.

Concerning Portugal, as teacher training has only prepared a handful of teachers to teach heritage education, few schools include it in their curriculum. In some cases, academic or professional meetings disseminated its teaching. Where present, heritage education usually complements existing local and community-based studies. However, student education about their heritage is an emerging factor that national curricula 
tentatively recognize in history, social sciences, arts and natural sciences (Pinto and Molina Puche, 2015).

History education might assume a decisive role in heritage and related museum education, since the study of heritage artefactual evidence and sites provides challenging opportunities for understanding Portugal's past, the development of students' historical thinking and emergent personal and national identities (Apostolidou, 2006; Cainelli, 2006; Estepa and Cuenca, 2006; Germinari, 2016; Levstik et al., 2005; Schmidt and Garcia, 2007; Hooper-Greenhill, 1999, 2007; Harnett, 2006; Nakou, 2001; Pinto, 2011; Ashby et al., 2005; Barca and Pinto, 2006; Cooper, 1992, 2004; Chapman, 2006).

Students' direct exploration and interpretation of heritage evidence means that their perceptions can provide research data to analyse how they comprehend the past and if they perceive the linkage between personal, familial, local, national and international events and trends. The critical task for the teacher is to help students dealing with questions and to support their investigations to reach and communicate their conclusions based upon them (Barton and Levstik, 2004). Understanding how students 'use' the past for temporal orientation is central to heritage education research. Temporal awareness is crucial for the study, analysis, interpretation and understanding of heritage sites and their past, present and even future significance (Pinto, 2013). Furthermore, understanding of the heritage legacy encourages reflective consciousness of our beliefs and identities, and even of others' cultures through the sharing of values, beliefs and attitudes.

\section{Constructing historical thinking and inclusive identities}

\section{Method and research questions}

The study was grounded in a historical and social sciences epistemological framework. It aimed to contribute to the understanding of how two cohorts of Portuguese students, mainly 12- and 15-year-olds, dealt with historical heritage sources, and how their teachers understood their use in history and social studies teaching and learning, with reference to interpretation as an element in historical thinking and understanding (Pinto, 2011, 2016). In order to answer the research problem - how do history teachers and students interpret evidence of a historical heritage site? - three research questions were formulated:

(1) How do students of seventh grade (mostly 12 years old) and tenth grade (mostly 15 years old) use historical heritage sites - spaces, buildings and related artefactual sources - as evidence of a changing past?

(2) What kind of historical thinking do students develop through direct exploration of local heritage?

(3) Within the school curriculum, what conceptions of heritage exploration do teachers reveal in activities that use heritage sources?

The study compared the views of students in two age groups using a descriptive, mainly qualitative approach based on Grounded Theory (Strauss and Corbin, 1998). Overall, the research investigated how students and their history teachers understood sources about the heritage, with a focus on the second research question: 'What kind of historical thinking do students develop through direct exploration of local heritage?'

The study involved 87 secondary students - 40 in the seventh grade (mostly 12 years old) and 47 in the tenth grade (mostly 15 years old) from five secondary 
schools in Guimarães, northern Portugal, and their six history teachers. The students' interpretation of heritage was through a paper-and-pencil activity on history learning outside the classroom (see Figure 1), focusing on several buildings and museum objects, some of them related to collective memory and others to a national narrative. The six history teachers who accompanied the group of students during the activity also answered two questionnaires, one before and one after the activity.

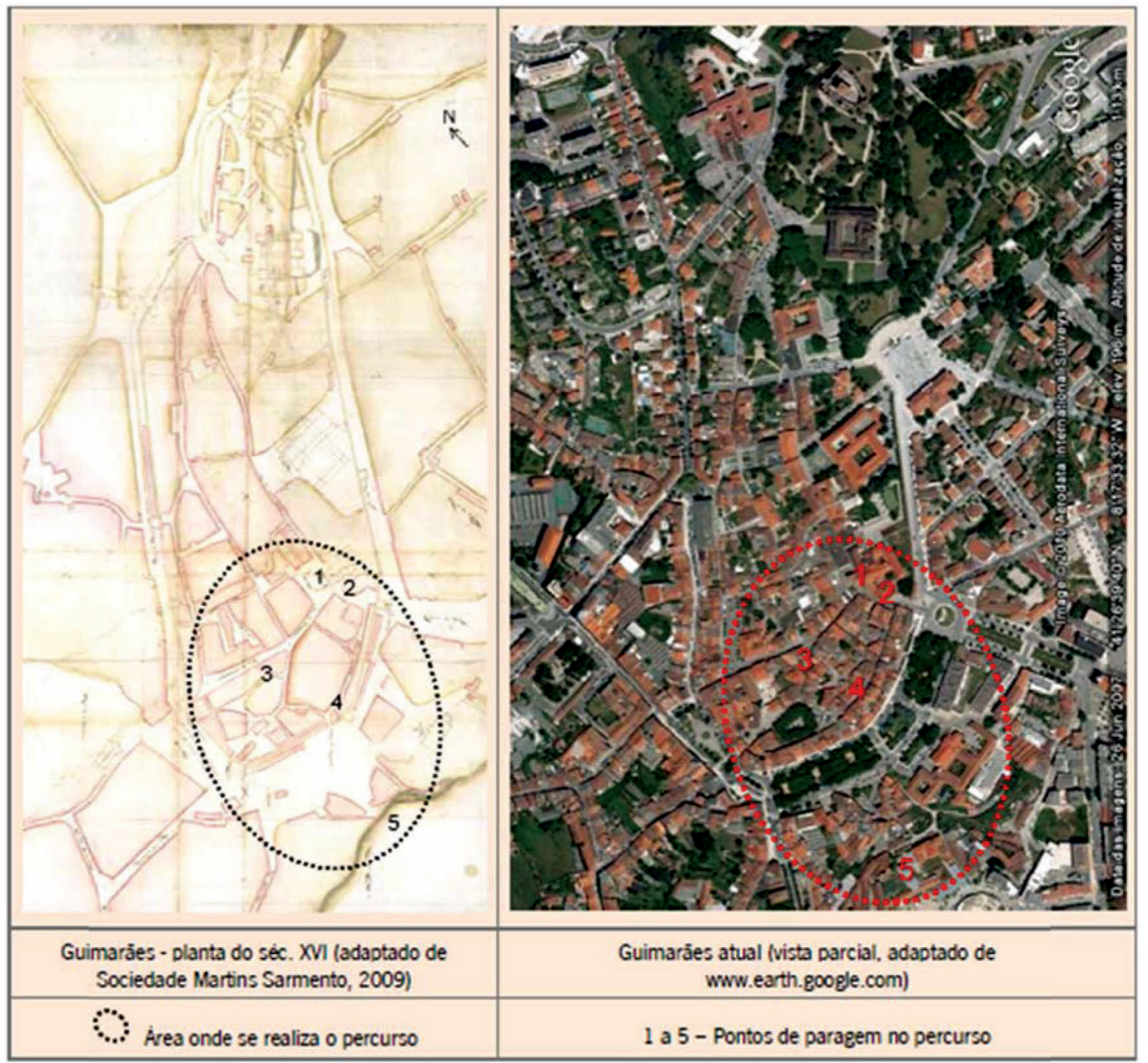

Figure 1: The first page of the questionnaire-guide presenting a sixteenth-century plan of Guimarães and a recent view of the town, both with the locations of the staging points

Source: Pinto (2011: 229)

The heritage education activity was based on history teaching pedagogy. The students' main learning aid was a questionnaire-guide that involved written tasks at specific points in the students' visit to the historic centre of the town of Guimarães. The tasks entailed direct observation and interpretation of heritage evidence related to the Middle Ages, but within a wider historical context. Each page of the questionnaire-guide involved a task that included background information about what they were observing at each point and three progressively more complex questions (see Figure 2) - 'What can you learn from it?'; 'What was its importance both to those who constructed it and to you?'; 'Which questions would you like to ask to know more about this place?'. The same set of questions applied to each point the students visited. 
Agora que já 'te situaste', podemos começar o nosso percurso...

Procura responder às questōes o melhor que souberes, seguindo o que tu pensas.

1. Junto à porta principal da igreja de Nossa Senhora da Oliveira, observa a lápide relativa à sua construção, que se encontra fixada na parede.
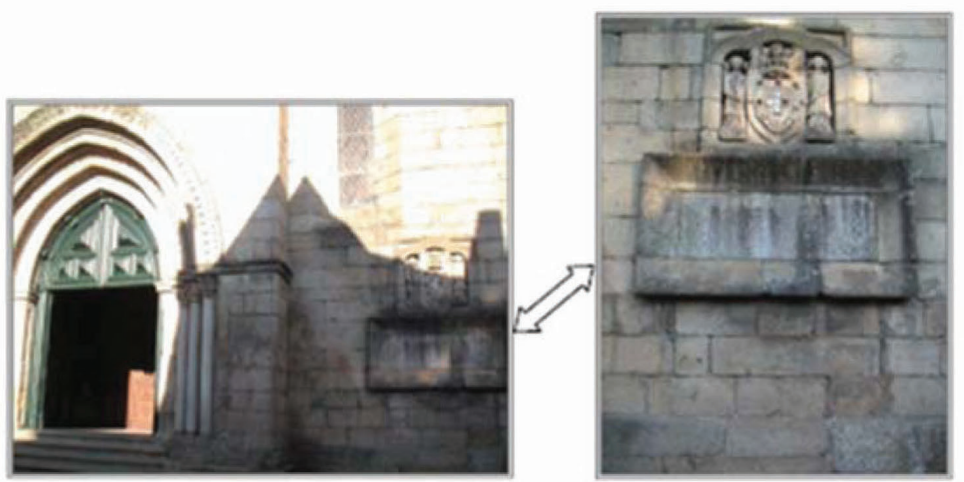

Será que consegues ler o texto? Podemos tentar ler em conjunto!

1.1. O que podes saber a partir do que observas?

1.2. Qual a sua importância para:

a) aqueles que o construiram?

b) hoje compreendermos a época em que foi construido?

a)

b)

1.3. Gostarias de colocar questões para tentares saber mais sobre este local? Quais?

Figure 2: Page of the questionnaire-guide concerning the first staging point - a plaque in the front of Sta. Maria da Oliveira church - with three questions of gradually increasing complexity

Source: Pinto (2011: 413)

\section{Categories of students' conceptions}

Analysis of the research data enabled the creation of student profiles concerning both their use of evidence and their historical consciousness: 47 per cent of students' answers regarding heritage remained focused on finding information from sources, with students conscious of a fixed past without any specific contextual knowledge about what they were studying; 28 per cent of students related their observations to their existing knowledge of their historical context, questioning and hypothesizing about the observed sources as historical evidence. 


\section{Use of evidence}

Analysis of students' conceptions concerning how they used information and inferred from their comprehension of the heritage sources revealed four levels of increasing sophistication:

(1) Alternative ideas: 10 per cent of responses demonstrated undefined or confused thoughts about the sources, or were inferences based on common-sense ideas and interpretations. Example: 'The person who did this wanted to present his work for those who want to know' (Alcina, Grade 7, age 13).

(2) Inference from existing details: 47 per cent of students regarded written and heritage sources as providing factual or functional details. They based their conjectures on superficial interpretations. Example: 'A king ordered the construction of this church' (Conceiçao, Grade 7, age 12).

(3) Inference from context: 25 per cent of students contextualized information within a broader framework of existing knowledge. Many answers revealed personal inferences based on such knowledge, setting information in a time sequence or establishing some link with the political, social and economic context. Conjectures suggested social and contextual concerns when interpreting heritage sources. Example: 'This house did not have always the same function, because it was a hospital in 1315, according to written sources, but before it probably was a shoemaker's house because of its founders' (Alexandra, Grade 10, age 15).

(4) Questioning: 3 per cent of student answers revealed personal inferences questioning the context in terms of evidence and relationship to time, or hypothesizing about diverse possibilities, or commenting on political, social and economic elements in the same context, or even making conjectures about several contexts in terms of temporal relationships. Example: 'Why did they think of building a square in memory of a war?' (Marlene, Grade 7, age 12).

\section{Historical consciousness}

Students' conceptions of how they made sense of the relationship between past and present depended on the personal and social significance they placed on interpreting heritage sources:

(1) Ahistorical consciousness: 10 per cent of student answers did not reveal ideas of social or personal significance concerning people's actions in the past, or revealed stereotypical ideas. Example: 'They had those tanks to wash their clothes, and we too' (Januário, Grade 7, age 12).

(2) Consciousness of a fixed past: To acquire knowledge about heritage, 52 per cent of students evaluated the actions of people of the past according to present values; or saw the past in generic terms as timeless; or conceived the past as an image of the present. Example: 'It is important because this monument is going to convey us the epoch and the meaning of the battle' (Eva, Grade 10, age 15).

(3) Consciousness of a symbolic past: 13 per cent revealed understanding of: how the continuation of heritage into the present, and its preservation, can be an evocation of key past events; the significance of heritage in terms of local or national identity (students value heritage as evoking a 'golden past'); how they refer to the past as a model for the present, expressing an emotional relationship between heritage identity; recognition of heritage as a symbol linked to a sense of national identity. Example: 'It is a symbol of a victory in a battle; it is national pride' (Justino, Grade 10, age 15). 
(4) Emerging historical consciousness: 18 per cent understood the relationship between past and present in a linear way from the socio-economic evidence in the heritage sources. Several answers revealed an emergent temporal orientation connected to contextualization and a sense of the diverse pace of change. Example: 'Ancient methods helped to develop new techniques and to understand how lives were in the past. Now inhabitants may acquire cultural knowledge about life in the town' (Pascoal, Grade 7, age 13).

(5) Explicit historical consciousness: Heritage students argued historically about the personal and social significance of heritage based on the relationship between social, economic, political, religious and cultural factors. They recognized change and continuity in the relationship between past, present and future. Of the answers, 3 per cent revealed an awareness of the historicity of heritage sources, recognizing contextualized interpretation as being essential to historical understanding. Example: 'We can situate ourselves spatially and temporally; with this legacy we may understand the ideas of that time, and how important was the veneration of saints (Amélia, Grade 10, age 16).

\section{Categories of teachers' conceptions}

There were two main teacher constructs that emerged from answers to questions before and after the student visit to the heritage site: 'Use of heritage evidence' and 'Aims of heritage teaching and making heritage accessible'.

\section{Use of heritage evidence}

Teachers' ideas concerning their role in establishing the relationship between remains from the past and their students' interpretations of them included:

(1) Undefined: Teachers broadly referred to the contribution of heritage activities to students' learning, avoiding clarifying how they could use heritage evidence.

(2) From context to evidence: Teachers initially perceived monuments, artefacts and historical sites as sources of information, rather than as providing evidence for use in historical investigations. They considered studying sources was relevant when related to their historical contextualization.

(3) Connecting evidence in context: Teachers did not see the past as a set of assorted fragments. An advantage of observing historical remains is that they help student confidence in treating heritage sources as historical evidence. Most teachers recognized that student interpretation of heritage sources enables students to develop historically contextualized understanding of heritage topics.

(4) From evidence to context: Teachers referred to a process of constructing knowledge based on evidence from the past, recognizing the fact that historical artefacts may provide insights into ways of life different from the present. Using a variety of sources and out-of-school activities related to local heritage can allow a multi-sensory approach to the past and stimulate significant historical dialogue between learners and the past.

\section{Aims of heritage teaching and making heritage accessible}

For teachers to be able to enhance students' heritage understanding through specific learning activities, they need to be aware of what thinking historically involves and 
how students can develop an understanding of the relationship between heritage and identity.

Among the ways in which teachers promote and enable student learning are:

(1) Motivating: Teachers expect students to see the past as something related to their everyday experience, revealing a tendency to find the past 'useful'. The danger of this is that it probably leads students to see the past as similar to the present, without them learning how to minimize such 'presentism' (Lee, 2005).

(2) Reinforcing knowledge: Teachers implicitly acknowledge that reinforcement is the main purpose of engaging with sources, including artefactual evidence. Some suggested that visiting historic sites and interpreting their historical evidence can help students make sense of the past.

(3) Building up knowledge: A more sophisticated response by teachers recognizes student construction of knowledge within a teacher-managed context that involves promotion of student dialogue with heritage sources and evidence.

Contributing to the historical consciousness dimension that can develop students' historical thinking and temporal orientation are:

(1) Information: Teachers believe that students' historical thinking will develop as a result of heritage site learning activities.

(2) Knowledge in context: Teachers recognize contextualized student understanding of the past is possible through their interpretation of heritage sources. Student understanding of the evidence and artefacts of a heritage site can enable them to recreate how people in the past used artefacts in their lives.

(3) Connecting changing times: Teachers' answers indicated an awareness of the historicity of heritage sources and that interpretation helps broaden and contextualize understanding of the complexity of relationships between the past and the present, and the diversity in change.

Contributing to the heritage awareness dimensions, that is, the influence it has on how students lead their lives, based on the relationship that they establish between identity and heritage when interpreting heritage sources, are:

(1) Diffuse ideas: Teachers emphasize respect for heritage through specific objects that can 'evoke' the past and must be preserved. This implies a commitment to a sense of collective identity that heritage awareness can strengthen.

(2) Sense of local identity: Teachers highlight that activities involving the direct observation of heritage sources stimulate the sense of belonging to a community and the awareness of the preservation of local heritage. They consider that this reinforces the identity of the community with historical roots.

(3) Sense of multiple identities: Teachers reveal an awareness that from the observation of a heritage site, it is possible to teach about identity issues. They consider that by exploiting sources of local heritage, students experience opportunities to deal with various types of identity, and to develop related contextualized historical understanding.

The constructs and categories analysed above concerning evidence, historical consciousness and heritage awareness have been developed and applied in history and heritage education curriculum development and research projects in Portugal, Spain and Brazil. Partnerships between schools and cultural institutions, such as museums and interpretation centres, are positive ways of linking heritage education projects with the community. An example is the selection and study of traditional and family artefacts that a fourth-grade class of primary school pupils in São Torcato, Guimarães, 
Portugal gathered during the school year 2016/17. Here the school's heritage club joined the Casa da Memória (House of Memory) in the project Ask the Time - which could be categorized within the bond-based model (Fontal and Ibañez-Etxeberria, 2017) - to promote heritage education in schools and communities referred to in this paper.

\section{Final considerations}

As a major dimension of history and social studies education, heritage education has countless possibilities for innovative pedagogic approaches that contribute to the development of historical and heritage consciousness and understanding of both teachers and students.

Awareness of interpretations in specific contexts is essential to historical understanding. Teachers should require students to analyse different, and sometimes controversial, interpretations of historical situations and their evidential basis - sources - with regard to historicity. Syllabuses including teaching about heritage need to provide students with opportunities to challenge preconceptions that they hold about heritage, and the sources on which they are based.

History education research has shown that, if not trained to think historically, the majority of students draw 'presentist' information and conclusions from studying historical sources (Ashby, 2005; Lee and Ashby, 2000). However, as Lee (2005) has suggested, a significant minority of students can use sources to identify and contextualize evidence about historical topics. Incrementally, they build up confidence in identifying evidence in historical sources, interpreting them in context using an analytical framework involving questioning, investigation, hypothesizing, conjecturing, testing of interpretations against the evidence and reaching conclusions. In the Portuguese heritage education project, some Grade 7, and a higher proportion of Grade 10, students inferred conclusions about social, economic and religious life in the Middle Ages at the heritage site from studying as evidence buildings, historical remains and artefacts that their existing historical knowledge contextualized and helped deepen their understanding.

Teachers will also enhance their own skills in the use of heritage in history and social sciences education, both through developing questions about museum artefacts and heritage site buildings, remains and artefacts, and also through educating students to investigate such sites as evidence about the past. History education pedagogy supports and encourages the development of heritage education research and development to contribute to the understanding of heritage and cultural changes at local, regional and national levels, rather than limiting heritage to the conservation of iconic symbols from an often mythical, sanitized past.

Emerging educational models and innovative didactic designs and applications, including the integration of information and communication technologies tools (for example, augmented reality apps), and appropriate evaluation criteria, will hopefully inform and shape curriculum research and development in heritage education as an element in national history and social studies.

\section{Acknowledgements}

This work was co-financed by [CITCEM] Fundo Europeu de Desenvolvimento Regional (FEDER) através do COMPETE 2020 - Programa Operacional Competitividade e Internacionalização (POCl) e por fundos nacionais através da FCT, no âmbito do 
projeto POCl-01-0145-FEDER-007460 and MINECO/FEDER, Proyecto 'Evaluación de programas y evaluación de aprendizajes en los ámbitos no formal e informal de la Educación Patrimonial' (EDU2015-65716-C2-2-R).

\section{Notes on the contributors}

Helena Pinto is a researcher at CITCEM (Transdisciplinary Research Centre, 'Culture, Space and Memory'), at the University of Porto. Her doctorate is in history and social science education, her master's degree in heritage and tourism and her first degree in history education. She teaches history and heritage education on lifelong learning programmes for teachers, and coordinates the production of heritage resources at local museums in northern Portugal.

Alex Ibañez-Etxeberria is a graduate in geography and history with a PhD in educational sciences. He is a full professor of social sciences didactics at the University of the Basque Country. As a specialist in heritage education, he has supervised four doctoral theses in this field, and undertaken research in Madrid, Porto, Cuenca (Ecuador) and Bologna. He is a member of the Network of Excellence in Social Sciences Teaching and Research (Red 14).

\section{References}

Apostolidou, E. (2006) 'The Historical Consciousness of 15-Year-Old Students in Greece'. Unpublished PhD thesis, Institute of Education, University of London.

Ashby, R. (2005) 'Students' approaches to validating historical claims'. In Ashby, R., Gordon, P. and Lee, P. (eds) Understanding History: Recent research in history education (International Review of History Education 4). London: RoutledgeFalmer, 21-36.

Ashby, R., Lee, P.J. and Shemilt, D. (2005) 'Putting principles into practice: Teaching and planning'. In Donovan, M.S. and Bransford, J.D. (eds) How Students Learn: History in the classroom. Washington, DC: National Academies Press, 79-178.

Barca, I. and Pinto, H. (2006) 'How children make sense of historic streets: Walking through downtown Guimarães'. International Journal of Historical Learning, Teaching and Research, $6(1), 2-9$

Barton, K.C. and Levstik, L.S. (2004) Teaching History for the Common Good. Mahwah, NJ: Lawrence Erlbaum Associates.

Cainelli, M. (2006) 'Educação Histórica: Perspectivas de aprendizagem da história no ensino fundamental'. Educar em revista, (número especial), 57-72.

Chapman, A. (2006) 'Asses, archers and assumptions: Strategies for improving thinking skills in history in years 9 to 13 '. Teaching History, 123, 6-13.

Chapman, A. and Facey, J. (2004) 'Placing history: Territory, story, identity - and historical consciousness'. Teaching History, 116, 36-41.

COE (Council of Europe) (1998) Recommendation No. R (98) 5 of the Committee of Ministers to Member States concerning Heritage Education (Adopted by the Committee of Ministers on 17 March 1998 at the 623rd meeting of the Ministers' Deputies). Online. https://rm.coe.int/ CoERMPublicCommonSearchServices/DisplayDCTMContent?documentld=09000016804f1 ca1 (accessed 4 July 2018).

Cooper, H. (1992) The Teaching of History: Implementing the national curriculum. London: David Fulton.

Cooper, H. (2004) 'Why time? Why place? Why play?'. In Cooper, H. (ed.) Exploring Time and Place through Play. London: David Fulton, 5-23.

Cuenca, J.M. (2002) 'El patrimonio en la didáctica de las ciencias sociales: Análisis de concepciones, dificultades y obstáculos para su integración en la enseñanza obligatoria'. Unpublished PhD thesis, University of Huelva.

Estepa, J. and Cuenca, J. (2006) 'La mirada de los maestros, profesores y gestores del patrimonio: Investigación sobre concepciones acerca del patrimonio y su didáctica'. In Calaf, R. and Fontal, O. (eds) Miradas al patrimonio. Gijón: Ediciones Trea, 51-71. 
Fontal Merillas, O. (2003) La educación patrimonial: Teoría y práctica en el aula, el museo e internet. Gijón: Ediciones Trea.

Fontal, O. and Ibañez-Etxeberria, A. (2017) 'Research on heritage education: Evolution and current state through analysis of high impact indicators'. Revista de Educación, 375, 184-214.

Germinari, G.D. (2016) 'History of the city in young students' historical consciousness'. In Schmidt, M.A. and Nechi, L. (eds) Brazilian Investigation in History Education. Curitiba: W.A. Editores, 103-18.

Harnett, P. (2006) 'Exploring the potential for history and citizenship education with primary children at the British Empire and Commonwealth Museum in Bristol'. International Journal of Historical Learning, Teaching and Research, 6 (1), 34-9.

Hooper-Greenhill, E. (1999) The Educational Role of the Museum. London: Routledge.

Hooper-Greenhill, E. (2007) Museums and Education: Purpose, pedagogy, performance. London: Routledge.

Lee, P. (2005) 'Putting principles into practice: Understanding history'. In Donovan, M.S. and Bransford, J.D. (eds) How Students Learn: History in the classroom. Washington, DC: The National Academies Press, 29-78.

Lee, P. and Ashby, R. (2000) 'Progression in historical understanding among students ages 7-14'. In Stearns, P.N., Seixas, P. and Wineburg, S. (eds) Knowing, Teaching, and Learning History: National and international perspectives. New York: New York University Press, 199-222.

Levstik, L.S., Henderson, A.G. and Schlarb, J.S. (2005) 'Digging for clues: An archaeological exploration of historical cognition'. In Ashby, R., Gordon, P. and Lee, P. (eds) Understanding History: Recent research in history education (International Review of History Education 4). London: RoutledgeFalmer, 37-53.

Lowenthal, D. (1999) The Past is a Foreign Country. Cambridge: Cambridge University Press.

Nakou, I. (2001) 'Children's historical thinking within a museum environment: An overall picture of a longitudinal study'. In Dickinson, A., Gordon, P. and Lee, P. (eds) Raising Standards in History Education (International Review of History Education 3). London: Woburn Press, 73-96.

Pinto, H. (2011) 'Educação Histórica e Patrimonial: Conceções de alunos e professores sobre o passado em espaços do presente'. Unpublished PhD thesis, Universidade do Minho.

Pinto, H. (2013) 'Challenging students' ideas on historical evidence by using heritage remains in field activities'. International Journal of Historical Learning, Teaching and Research, $12(1), 121-36$

Pinto, H. (2016) 'Local heritage approaches in history education: Understanding how decisions of people in the past led to the present'. International Journal of Historical Learning, Teaching and Research, 13 (2), 70-81.

Pinto, H. and Molina Puche, S. (2015) 'La educación patrimonial en los currículos de ciencias sociales en España y Portugal'. Educatio Siglo XXI, 33 (1), 103-28.

Schmidt, M.A. and Garcia, T.B. (2007) 'O trabalho com objetos e as possibilidades de superação do sequestro da cognição histórica: Estudo de caso com crianças nas séries iniciais'. In Schmidt, M.A. and Garcia, T.B. (eds) Perspectivas de Investigação em Educação Histórica. Curitiba: UFPR, 52-7.

Strauss, A. and Corbin, J. (1998) Basics of Qualitative Research: Techniques and procedures for developing grounded theory. 2nd ed. Thousand Oaks, CA: SAGE Publications.

UNESCO (United Nations Educational, Scientific and Cultural Organization) (1972) 'Convention concerning the Protection of the World Cultural and Natural Heritage 1972'. Online. http://portal.unesco.org/en/ev.php-URL_ID=13055\&URL_DO=DO_TOPIC\&URL_SECTION=201. html (accessed 24 June 2017).

UNESCO (United Nations Educational, Scientific and Cultural Organization) (2003) 'UNESCO Declaration concerning the Intentional Destruction of Cultural Heritage'. Online. http://portal. unesco.org/en/ev.php-URL_ID=17718\&URL_DO=DO_TOPIC\&URL_SECTION=201.html (accessed 24 June 2017). 